\title{
Herbaspirillum chlorophenolicum sp. nov., a 4-chlorophenol-degrading bacterium
}

Correspondence
Sung Taik Lee
e_stlee@kaist.ac.kr

\author{
Wan-Taek Im, ${ }^{1}$ Hee-Sung Bae, ${ }^{2}$ Akira Yokota $^{3}$ and Sung Taik Lee ${ }^{1}$ \\ ${ }^{1}$ Department of Biological Sciences, Korea Advanced Institute of Science and Technology, \\ 373-1, Guseong-dong, Yuseong-gu, Daejeon 305-701, Korea \\ ${ }^{2}$ Department of Biological Sciences, 331 Life Sciences Building, LSU, Baton Rouge, \\ LA 70803, USA \\ ${ }^{3}$ Institute of Molecular and Cellular Biosciences, University of Tokyo, 1-1, Yayoi 1-chome, \\ Bunkyo-ku, Tokyo, 113-0032, Japan
}

\begin{abstract}
A 4-chlorophenol-degrading bacterial strain, formerly designated as a strain of Comamonas testosteroni, was reclassified as a member of the genus Herbaspirillum based on its phenotypic and chemotaxonomic characteristics, as well as phylogenetic analysis using $16 \mathrm{~S}$ rDNA sequences. Phylogenetic inference based on $16 \mathrm{~S}$ rDNA sequences showed that strain $\mathrm{CPW} 301^{\top}$ clusters in a phylogenetic branch that contains Herbaspirillum species. 16S rDNA sequence similarity of strain CPW $301^{\top}$ to species of the genus Herbaspirillum with validly published names is in the range 98.7-98.9\%. Despite the considerably high $16 \mathrm{~S}$ rDNA sequence similarity, strain CPW301 ${ }^{\top}$ could be distinguished clearly from type strains of Herbaspirillum species with validly published names by DNA-DNA relatedness values, which were $<15 \cdot 7 \%$. The genomic DNA $G+C$ content of strain CPW301 ${ }^{\top}$ is $61.3 \mathrm{~mol} \%$. The predominant ubiquinone is Q-8 and the major cellular fatty acids are $\mathrm{C}_{16: 0}$ and cyclo- $\mathrm{C}_{17: 0}$. The strain does not fix nitrogen and is not plant-associated. It is an aerobic rod with one unipolar flagellum. On the basis of these characteristics, a novel Herbaspirillum species, Herbaspirillum chlorophenolicum sp. nov., is proposed. The type strain of the novel species is strain CPW $301^{\top}\left(=\mathrm{KCTC}_{12096^{\top}}=\mathrm{IAM} 15024^{\top}\right)$.
\end{abstract}

The bacterial genus Herbaspirillum includes four species with validly published names: Herbaspirillum seropedicae, Herbaspirillum rubrisubalbicans, Herbaspirillum frisingense and Herbaspirillum lusitanum. H. seropedicae $\mathrm{Z}^{2} 7^{\mathrm{T}}$ (=IAM $14977^{\mathrm{T}}$ ), isolated from cereal roots, was the first species to be reported in this genus (Baldani et al., 1986). Later, a mild plant pathogen, formerly named Pseudomonas rubrisubalbicans, was reclassified as $H$. rubrisubalbicans LMG $2286^{\mathrm{T}}$ ( = IAM 14976 ${ }^{\mathrm{T}}$ ) (Baldani et al., 1996). Kirchhof et al. (2001) identified a nitrogen-fixing bacterium, isolated from C4fibre plants, as $H$. frisingense GSF30 ${ }^{\mathrm{T}}$ (=IAM $14974^{\mathrm{T}}$ ). More recently, $H$. lusitanum $\mathrm{LMG} 21710^{\mathrm{T}}$ was isolated from root nodules of Phaseolus vulgaris plants and proposed as a novel species by Valverde et al. (2003). Although the unnamed Herbaspirillum species 3 (Baldani et al., 1996) did not fix nitrogen, all type strains of species with validly

Published online ahead of print on 27 February 2004 as DOI 10.1099/ ijs.0.02812-0.

The GenBank/EMBL/DDBJ accession number for the 16S rDNA sequence of strain $\mathrm{CPW} 01^{\top}\left(=\mathrm{KCTC} 12096^{\top}=\mathrm{IAM} 15024^{\top}\right)$ is AB094401.

A phylogenetic tree and DNA-DNA relatedness data are available as supplementary material in IJSEM Online. published names have been recognized as nitrogen-fixing micro-organisms.

Chlorophenols are common environmental pollutants that arise from extensive use of wood preservatives, herbicides and fungicides and they are found frequently in pulpbleaching effluents and industrial wastewater (Kringstad \& Lindström, 1984; Valo et al., 1984, 1985). Due to the environmentally hazardous properties of chlorophenols, intensive attention has been paid to processes of microbial chlorophenol degradation. Many micro-organisms have been reported to degrade chlorophenols as their sole carbon and energy source, including a Pseudomonas species (Knackmuss \& Hellwig, 1978; Radehaus \& Schmidt, 1992), Arthrobacter species (Stanlake \& Finn, 1982; Li et al., 1991), Rhodococcus chlorophenolicus (Apajalahti et al., 1986) and some Flavobacterium strains (Saber \& Crawford, 1985). In our laboratory, Bae et al. (1996) previously reported a 4-chlorophenol-degrading bacterium, strain CPW $301^{\mathrm{T}}$, that was isolated from soil sediment collected in a stream near an industrial region in Cheongju, Korea, via selective enrichment with 4 -chlorophenol as the sole carbon and energy source. It was identified tentatively as a strain of Comamonas testosteroni on the basis of its morphological and physiological characteristics. In the present study, 
phylogenetic analysis on the basis of $16 \mathrm{~S}$ rDNA sequences was performed and DNA-DNA relatedness and some important phenotypic characteristics were examined to determine the precise taxonomic position of this strain. On the basis of the results obtained in this study, it is proposed that strain $\mathrm{CPW} 301^{\mathrm{T}}$ should be placed in the genus Herbaspirillum as the type strain of a novel species, namely Herbaspirillum chlorophenolicum sp. nov.

Strain CPW $301^{\mathrm{T}}$ was originally isolated from soil sediment that was collected in a stream near an industrial region (Cheongju, Korea) (Bae et al., 1996) and deposited in the Korean Collection for Type Cultures as KCTC $12096^{\mathrm{T}}$ $\left(=\right.$ IAM $\left.15024^{\mathrm{T}}\right)$. H. seropedicae IAM $14977^{\mathrm{T}}$, H. rubrisubalbicans IAM $14976^{\mathrm{T}}$ and $H$. frisingense IAM $14974^{\mathrm{T}}$ were obtained from the IAM Culture Collection, Institute of Molecular and Cellular Bioresources, University of Tokyo, Tokyo, Japan. Flagellation and morphological characteristics were determined by transmission electron microscopy after staining cells negatively with $1 \%(\mathrm{w} / \mathrm{v})$ phosphotungstic acid. Gram-staining and catalase and oxidase tests were performed according to procedures outlined by Smibert \& Krieg (1981). Substrate utilization and some physiological characteristics were determined with API 20 NE, ID 32 GN and API 50 CHB kits (bioMérieux).

Phenol- and 4-chlorophenol-degradation ability was assessed in a $500 \mathrm{ml}$ Erlenmeyer flask that contained $50 \mathrm{ml}$ mineral salts medium (Bae et al., 1996) with $0.5 \mathrm{mM}$ phenol or $0.5 \mathrm{mM}$ 4-chlorophenol as the sole carbon source in a shaking incubator at $30{ }^{\circ} \mathrm{C}$. Nitrogenfixing ability was determined by growth in $50 \mathrm{ml}$ nitrogenfree medium (DSMZ medium no. 3) in a $500 \mathrm{ml}$ Erlenmeyer flask. The medium contained $\left[(1 \text { distilled water })^{-1}\right]: 5 \cdot 0 \mathrm{~g}$ glucose; $5 \cdot 0$ g mannitol; $0 \cdot 1 \mathrm{~g} \mathrm{CaCl}_{2} \cdot 2 \mathrm{H}_{2} \mathrm{O} ; 0 \cdot 1 \mathrm{~g} \mathrm{MgSO}_{4} \cdot 7 \mathrm{H}_{2} \mathrm{O}$; $5.0 \mathrm{mg} \mathrm{Na} 2 \mathrm{MoO}_{4} \cdot 2 \mathrm{H}_{2} \mathrm{O} ; 0.9 \mathrm{~g} \mathrm{~K}_{2} \mathrm{HPO}_{4} ; 0 \cdot 1 \mathrm{~g} \mathrm{KH}_{2} \mathrm{PO}_{4}$; $0 \cdot 01 \mathrm{~g} \mathrm{FeSO}_{4} .7 \mathrm{H}_{2} \mathrm{O} ; 5 \cdot 0 \mathrm{~g} \mathrm{CaCO}_{3}$; and $1 \mathrm{ml}$ trace element mixture. The trace element mixture (SL-6, DSMZ medium no. 27) contained [(l distilled water $)^{-1}$ ]: $0 \cdot 1 \mathrm{~g} \mathrm{ZnSO}_{4} \cdot 7 \mathrm{H}_{2} \mathrm{O}$; $0.03 \mathrm{~g} \mathrm{MnCl}_{2} .4 \mathrm{H}_{2} \mathrm{O} ; 0.3 \mathrm{~g} \mathrm{H}_{3} \mathrm{BO}_{3} ; 0.2 \mathrm{~g} \mathrm{CoCl}_{2} .6 \mathrm{H}_{2} \mathrm{O}$; $0.01 \mathrm{~g} \mathrm{CuCl}_{2} \cdot 2 \mathrm{H}_{2} \mathrm{O}$; and $0.02 \mathrm{~g} \mathrm{NiCl}_{2} \cdot 6 \mathrm{H}_{2} \mathrm{O}$. Growth was determined after 2 weeks at $30{ }^{\circ} \mathrm{C}$ in a shaking incubator.

Ubiquinones were extracted from cells that had been grown on nutrient broth (Difco) and were analysed as described by Komagata \& Suzuki (1987), using reverse-phase HPLC. Cellular fatty acids were analysed in strains CPW $301^{\mathrm{T}}, H$. frisingense IAM $14974^{\mathrm{T}}, H$. rubrisubalbicans IAM $14976^{\mathrm{T}}$ and $H$. seropedicae IAM $14977^{\mathrm{T}}$, grown on trypticase soy agar (Difco) for 1-2 days. Cellular fatty acids were saponified, methylated and extracted according to the protocol of the Sherlock Microbial Identification system (MIDI). Fatty acids were analysed by GC (Hewlett Packard 6890) and identified by the Microbial Identification software package (Sasser, 1990).

Chromosomal DNA was extracted from cells that had been grown on a nutrient agar plate (Difco) as described by Ausubel et al. (1995). RNA in the DNA solution was removed by incubation with a mixture of ribonucleases $\mathrm{A}$ and $\mathrm{T} 1$ (each at $20 \mathrm{U} \mathrm{ml}^{-1}$ ) at $30^{\circ} \mathrm{C}$ for $1 \mathrm{~h}$. Chromosomal DNA $\mathrm{G}+\mathrm{C}$ content was analysed as described by Mesbah et al. (1989), using reverse-phase HPLC. DNA-DNA relatedness was determined as described by Ezaki et al. (1989), using photobiotin-labelled DNA probes and micro-dilution wells.

Two pairs of primer systems, Fdb261-Fdb260 (Stoltzfus et al., 1997) and PolF-PolR (Poly et al., 2001), were used to amplify the nifD and nifH genes, respectively. PCR was run for 35 cycles with a DNA thermal cycler (model 2400; Perkin-Elmer). The following thermal profiles were used for PCR: denaturation at $94^{\circ} \mathrm{C}$ for $45 \mathrm{~s}$, primer annealing at $50{ }^{\circ} \mathrm{C}$ for $45 \mathrm{~s}$ and extension at $72^{\circ} \mathrm{C}$ for $45 \mathrm{~s}$. The final cycle included an extension for $7 \mathrm{~min}$. PCR products were separated by electrophoresis on an agarose gel $(0 \cdot 8 \%$, w/v) and stained with ethidium bromide. Band size was determined by comparison with a 100 bp ladder standard (Bio-Rad).

16S rDNA was amplified from chromosomal DNA of strain $\mathrm{CPW} 301^{\mathrm{T}}$ by using a universal eubacterial primer set, 9F [5'-GAGTTTGATCCTGGCTCAG-3'; positions 9-27 (Escherichia coli 16S rDNA numbering)] and 1512R [5'ACGG(H)TACCTTGTTACGACTT-3'; positions 1512-1492] (Weisburg et al., 1991). The PCR product, purified with a GFX PCR DNA and Gel Band Purification kit (Amersham Biosciences), was sequenced with an ABI Prism BigDye Terminator Cycle Sequencing Ready Reaction kit (Applied Biosystems) and an automatic DNA sequencer (model 310; Applied Biosystems). Primers used for full sequencing were 9F, 1512R, 341F [5'-CCTACGGGAGGCAGCAG-3'; positions 341-357 (E. coli 16S rDNA numbering)], 519F [5'-CAGCAGCCGCGGTAATAC-3'; positions 519-536], 907F [5'-AAACTCAAAKGAATTGACGG-3'; positions 907-926], 536R [5'-GTATTACCGCGGCTGCTG-3'; positions 536-519] and 1100R [5'-GGGTTGCGCTCGTTG-3'; positions 1114-1110]. The partial 16S rDNA sequences were combined in the program BioEdit (Hall, 1999). 16S rDNA sequences of related taxa were obtained from GenBank. Multiple alignments were performed by using CLUSTAL_X (Thompson et al., 1997). Gaps were edited in BioEdit (Hall, 1999). Evolutionary distances were calculated by using the Kimura two-parameter model (Kimura, 1983). A phylogenetic tree was constructed by using the neighbour-joining method (Saitou \& Nei, 1987) in the program MEGA2 (Kumar et al., 2001). A neighbour-joining bootstrap method was used to obtain confidence levels for the neighbour-joining analysis, with a bootstrap dataset of 1000 (Felsenstein, 1985).

Strain $\mathrm{CPW} 301^{\mathrm{T}}$ is an aerobic, Gram-negative, motile and slightly curved rod $(0.7 \mu \mathrm{m}$ in diameter and $2 \cdot 3 \mu \mathrm{m}$ long $)$ with one unipolar flagellum. Colonies that form on nutrient agar plates (Difco) are smooth, circular, non-glossy, brownish and convex. The strain gave positive results for catalase, oxidase and urease. Nitrate was not reduced to nitrite. The strain grew well at $30^{\circ} \mathrm{C}$ and $\mathrm{pH} 6-8$, but did not grow well at $45^{\circ} \mathrm{C}$. These morphological and physiological 
characteristics are summarized in Table 1, along with data for Herbaspirillum species with validly published names. nifD and nifH are genes that encode key enzymes in nitrogen-fixing pathways in various micro-organisms (Yong, 1992). An attempt was made to detect these genes in strain CPW $301^{\mathrm{T}}$ by a PCR amplification approach using

Table 1. Comparison of characteristics of strain CPW $301^{\top}$, Herbaspirillum species and C. testosteroni

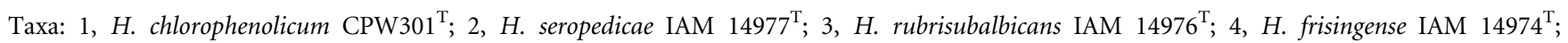
5, H. lusitanum LMG $21760^{\mathrm{T}}$; 6, C. testosteroni ATCC $11996^{\mathrm{T}}$. Characteristic results for H. seropedicae IAM $14977^{\mathrm{T}}$, H. rubrisubalbicans IAM $14976^{\mathrm{T}}$, H. frisingense IAM $14974^{\mathrm{T}}$, H. lusitanum LMG $21760^{\mathrm{T}}$ and C. testosteroni ATCC $11996^{\mathrm{T}}$ are from Baldani et al. (1986, 1996), Kirchhof et al. (2001), Valverde et al. (2003) and Chang et al. (2002). The following characteristics were determined in this study: detection of nifD and nifH, growth on phenol and 4-chlorophenol and fatty acid composition. +, Positive; -, negative; ND, not determined; TR, trace $(<0 \cdot 5 \%)$.

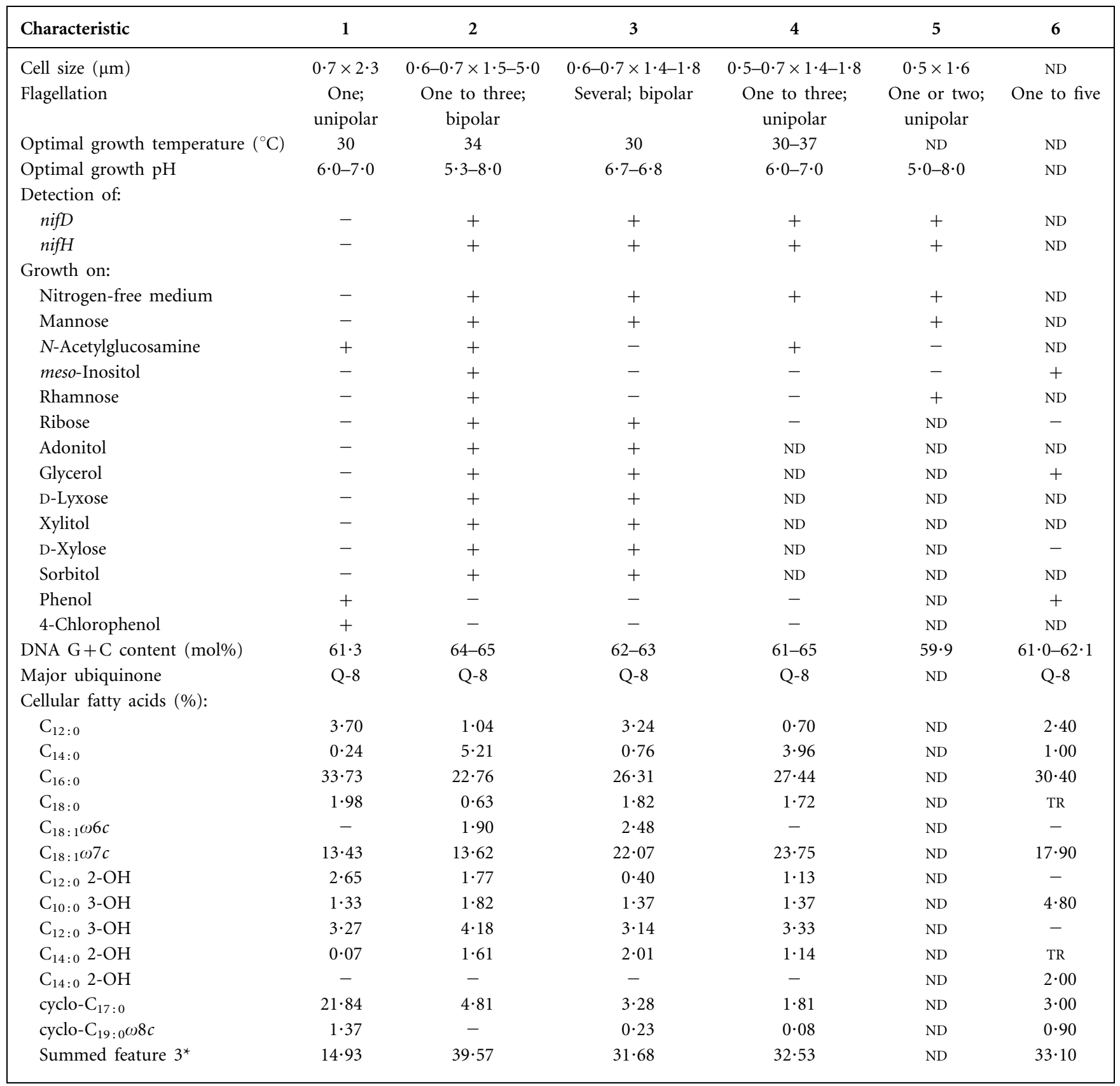

${ }^{*}$ Summed feature 3 contains $\mathrm{C}_{16: 1} \omega 7 c$ and/or iso- $\mathrm{C}_{15: 0}$ 2-OH; these fatty acids could not be separated by GLC with the Microbial Identification system (MIDI). 
two primer systems [Fdb261-Fdb260 for nifD (Stoltzfus et al., 1997) and PolF-PolR for nifH (Poly et al., 2001)], in order to determine whether the strain has the genetic capability to fix nitrogen. These genes, nifD (about $390 \mathrm{bp}$ ) and nifH (about $360 \mathrm{bp}$ ), were clearly amplified in nitrogenfixing type strains, whereas they were not amplified in strain CPW $301^{\mathrm{T}}$ (Table 1). Strain CPW $301^{\mathrm{T}}$ did not grow in a nitrogen-free liquid medium, whereas Herbaspirillum species with validly published names grew well (Table 1).

Strain $\mathrm{CPW} 301^{\mathrm{T}}$ and all the type strains had Q-8 as the predominant ubiquinone. The major fatty acids of strain CPW301 ${ }^{\mathrm{T}}$ were $\mathrm{C}_{16: 0}(33 \cdot 7 \%)$, cyclo- $\mathrm{C}_{17: 0}(21 \cdot 8 \%)$, summed feature $3(14.9 \%)$ and $\mathrm{C}_{18: 1} \omega 7 c(13.4 \%)$. Although the proportions are slightly different, these fatty acids are also observed in the type strains of Herbaspirillum species (Table 1). The DNA G $+\mathrm{C}$ content of strain $\mathrm{CPW} 301^{\mathrm{T}}$ was $61.3 \mathrm{~mol} \%$; this value is similar to those of the type strains of Herbaspirillum species (60-65\%).

Almost all of the $16 \mathrm{~S}$ rDNA sequence (1474 nt) of strain CPW $301^{\mathrm{T}}$ was determined in this study. Phylogenetic analysis of $16 \mathrm{~S}$ rDNA sequences showed that strain $\mathrm{CPW} 301^{\mathrm{T}}$ fell in a cluster that comprised Herbaspirillum species (a phylogenetic tree is available as supplementary material in IJSEM Online). The $16 \mathrm{~S}$ rDNA sequence similarities of strain $\mathrm{CPW} 301^{\mathrm{T}}$ to $H$. frisingense IAM $14974^{\mathrm{T}}, H$. rubrisubalbicans IAM $14976^{\mathrm{T}}, H$. seropedicae IAM $14977^{\mathrm{T}}$ and H. lusitanum LMG $21710^{\mathrm{T}}$ are $98 \cdot 9,98 \cdot 7$, 98.8 and $97.5 \%$, respectively. Strain $\mathrm{CPW} 301^{\mathrm{T}}$ exhibited DNA-DNA relatedness levels of $<15 \cdot 7 \%$ to $H$. frisingense IAM $14974^{\mathrm{T}}, H$. rubrisubalbicans IAM $14976^{\mathrm{T}}$ and H. seropedicae IAM $14977^{\mathrm{T}}$ (hybridization data are available as supplementary material in IJSEM Online).

Phylogenetic analysis based on $16 \mathrm{~S}$ rDNA sequences indicates clearly that strain $\mathrm{CPW} 301^{\mathrm{T}}$ is placed in the radiation of the cluster that contains Herbaspirillum species. The names of three species of Herbaspirillum, $H$. seropedicae (Baldani et al., 1986), H. rubrisubalbicans (Baldani et al., 1996) and H. frisingense (Kirchhof et al., 2001), have been validly published and another species ( $H$. lusitanum) has recently been proposed as a member of the genus Herbaspirillum by Valverde et al. (2003). Strain CPW $301^{\mathrm{T}}$ has similar morphological features to the type strains of these species and it also shares many physiological characteristics with them (Table 1). Furthermore, chemotaxonomic characteristics of $\mathrm{CPW} 301^{\mathrm{T}}$ determined in this study, e.g. ubiquinone, fatty acids and DNA G + C content, are well-matched to those of other Herbaspirillum species (Table 1). The phylogenetic, phenotypic and chemotaxonomic results described in this study support classification of strain CPW $301^{\mathrm{T}}$ in the genus Herbaspirillum.

It is worthwhile to compare the phenotypic characteristics of strain $\mathrm{CPW}_{301} \mathrm{1}^{\mathrm{T}}$ with those of the type strain of C. testosteroni, as our strain was originally classified in this species (Bae et al., 1996). Our strain differs from C. testosteroni in meso-inositol and glycerol utilization and fatty acid profile (Table 1). Thus, in addition to phylogenetic data, phenotypic characteristics support reclassification of strain $\mathrm{CPW}_{301}{ }^{\mathrm{T}}$ in the genus Herbaspirillum.

Strain CPW301 ${ }^{\mathrm{T}}$ showed $98 \cdot 7-98 \cdot 9 \% 16 \mathrm{~S}$ rDNA similarity to the type strains of Herbaspirillum species. Where $16 \mathrm{~S}$ rDNA sequence similarity is $>97 \%$, DNA-DNA relatedness values play an important role in clarifying intergeneric relationships between species (Stackebrandt \& Goebel, 1994). Strain CPW $301^{\mathrm{T}}$ exhibited $<15 \cdot 7 \%$ DNA-DNA relatedness to species of Herbaspirillum with validly published names. This level is low enough for strain CPW $301^{\mathrm{T}}$ to be classified in a novel Herbaspirillum species (Wayne et al., 1987). Furthermore, strain CPW $301^{\mathrm{T}}$ can also be distinguished from Herbaspirillum species with validly published names with respect to some important physiological characteristics. For example, all the type strains of described Herbaspirillum species are nitrogen-fixing organisms (Baldani et al., 1986, 1996; Kirchhof et al., 2001), whereas strain $\mathrm{CPW} 301^{\mathrm{T}}$ did not grow in a nitrogen-free liquid medium and did not have the nifD or nifH genes, suggesting that it may not have a nitrogen-fixing ability. Substrateutilization properties (Table 1) also differ between strain CPW $301^{\mathrm{T}}$ and the type strains of Herbaspirillum species. On the basis of the data and observations described above, strain $\mathrm{CPW} 301^{\mathrm{T}}$ should be assigned to the genus Herbaspirillum as the type strain of a novel species, for which the name Herbaspirillum chlorophenolicum sp. nov. is proposed.

\section{Description of Herbaspirillum chlorophenolicum sp. nov.}

Herbaspirillum chlorophenolicum (chlo.ro.phen.o'li.cum. Gr. n. adj. chloros greenish-yellow, containing chloride; N.L. adj. phenolicus relating to phenol; N.L. neut. adj. chlorophenolicum relating to chlorophenols).

Gram-negative, aerobic, motile, slightly curved rods, $0.7 \mu \mathrm{m}$ in diameter and $2.3 \mu \mathrm{m}$ long, after culture for 1 day on nutrient agar. Cells have one unipolar flagellum. Colonies grown on nutrient agar (Difco) for 1-2 days are smooth, circular, non-glossy, brownish and convex. Grows well at $30^{\circ} \mathrm{C}$ and $\mathrm{pH} 6-8$, but does not grow at $45^{\circ} \mathrm{C}$. Substrate utilization, enzyme production, acid production and other physiological characteristics are indicated in Table 1. Does not have nifD or nifH genes. Q-8 is the predominant ubiquinone. $\mathrm{C}_{16: 0}$ and cyclo- $\mathrm{C}_{17: 0}$ are the major cellular fatty acids. DNA G+C content of the type strain is $61.3 \mathrm{~mol} \%$ (as determined by HPLC).

The type strain, CPW $301^{\mathrm{T}}\left(=\mathrm{KCTC} 12096^{\mathrm{T}}=\mathrm{IAM} 15024^{\mathrm{T}}\right)$, was isolated from soil sediment that was collected at a stream near an industrial region in Cheongju, Korea.

\section{Acknowledgements}

This work was supported by grants from the 21C Frontier Microbial Genomics and Applications Center Program, Ministry of Science and Technology, grant MG02-0101-001-2-2-0. 


\section{References}

Apajalahti, J. H. A., Kärpänoja, P. \& Salkinoja-Salonen, M. S. (1986). Rhodococcus chlorophenolicus sp. nov., a chlorophenol-mineralizing actinomycete. Int J Syst Bacteriol 36, 246-251.

Ausubel, F. M., Brent, R., Kingston, R. E., Moore, D. D., Seidman, J. G., Smith, J. A. \& Struhl, K. (1995). Current Protocols in Molecular Biology. New York: Wiley.

Bae, H.-S., Lee, J. M., Kim, Y. B. \& Lee, S. T. (1996). Biodegradation of the mixtures of 4-chlorophenol and phenol by Comamonas testosteroni CPW301. Biodegradation 7, 463-469.

Baldani, J. I., Baldani, V. L. D., Seldin, L. \& Döbereiner, J. (1986). Characterization of Herbaspirillum seropedicae gen. nov., sp. nov., a root-associated nitrogen-fixing bacterium. Int J Syst Bacteriol 36, 86-93.

Baldani, J. I., Pot, B., Kirchhof, G. \& 8 other authors (1996). Emended description of Herbaspirillum; inclusion of [Pseudomonas] rubrisubalbicans, a mild plant pathogen, as Herbaspirillum rubrisubalbicans comb. nov.; and classification of a group of clinical isolates (EF group 1) as Herbaspirillum species 3. Int J Syst Bacteriol 46, 802-810.

Chang, Y.-H., Han, J., Chun, J., Lee, K. C., Rhee, M.-S., Kim, Y.-B. \& Bae, K. S. (2002). Comamonas koreensis sp. nov., a non-motile species from wetland in Woopo, Korea. Int J Syst Evol Microbiol 52, 377-381.

Ezaki, T., Hashimoto, Y. \& Yabuuchi, E. (1989). Fluorometric deoxyribonucleic acid-deoxyribonucleic acid hybridization in microdilution wells as an alternative to membrane filter hybridization in which radioisotopes are used to determine genetic relatedness among bacterial strains. Int J Syst Bacteriol 39, 224-229.

Felsenstein, J. (1985). Confidence limits on phylogenies: an approach using the bootstrap. Evolution 39, 783-791.

Hall, T. A. (1999). BioEdit: a user-friendly biological sequence alignment editor and analysis program for Windows 95/98/NT. Nucleic Acids Symp Ser 41, 95-98.

Kimura, M. (1983). The Neutral Theory of Molecular Evolution. Cambridge: Cambridge University Press.

Kirchhof, G., Eckert, B., Stoffels, M., Baldani, J. I., Reis, V. M. \& Hartmann, A. (2001). Herbaspirillum frisingense sp. nov., a new nitrogen-fixing bacterial species that occurs in C4-fibre plants. Int $J$ Syst Evol Microbiol 51, 157-168.

Knackmuss, H.-J. \& Hellwig, M. (1978). Utilization and cooxidation of chlorinated phenols by Pseudomonas sp. B13. Arch Microbiol 117, $1-7$.

Komagata, K. \& Suzuki, K. (1987). Lipid and cell wall analysis in bacterial systematics. Methods Microbiol 19, 161-206.

Kringstad, K. P. \& Lindström, K. (1984). Spent liquors from pulp bleaching. Environ Sci Technol 18, 236A-242A, 245A-248A.

Kumar, S., Tamura, K., Jakobsen, I. B. \& Nei, M. (2001). MEGA2: molecular evolutionary genetic analysis software. Bioinformatics 17, $1244-1245$.

Li, D.-Y., Eberspächer, J., Wagner, B., Kuntzer, J. \& Lingens, F. (1991). Degradation of 2,4,6-trichlorophenol by Azotobacter sp. strain GP1. Appl Environ Microbiol 57, 1920-1928.

Mesbah, M., Premachandran, U. \& Whitman, W. B. (1989). Precise measurement of the $\mathrm{G}+\mathrm{C}$ content of deoxyribonucleic acid by highperformance liquid chromatography. Int J Syst Bacteriol 39, 159-167.
Poly, F., Monrozier, L. J. \& Bally, R. (2001). Improvement in the RFLP procedure for studying the diversity of nifH genes in communities of nitrogen fixers in soil. Res Microbiol 152, 95-103.

Radehaus, P. M. \& Schmidt, S. K. (1992). Characterization of a novel Pseudomonas sp. that mineralizes high concentrations of pentachlorophenol. Appl Environ Microbiol 58, 2879-2885.

Saber, D. L. \& Crawford, R. L. (1985). Isolation and characterization of Flavobacterium strains that degrade pentachlorophenol. Appl Environ Microbiol 50, 1512-1518.

Saitou, N. \& Nei, M. (1987). The neighbor-joining method: a new method for reconstructing phylogenetic trees. Mol Biol Evol 4, 406-425.

Sasser, M. (1990). Identification of Bacteria by Gas Chromatography of Cellular Fatty Acids (technical note no. 101). Newark, DE: MIDI Inc. (http://www.midi-inc.com/media/pdfs/TechNote_101.pdf).

Smibert, R. M. \& Krieg, N. R. (1981). General characterization. In Manual of Methods for General Bacteriology, pp. 409-443. Edited by P. Gerhardt, R. G. E. Murray, R. N. Costilow, E. W. Nester, W. A. Wood, N. R. Krieg \& G. B. Phillips. Washington, DC: American Society for Microbiology.

Stackebrandt, E. \& Goebel, B. M. (1994). Taxonomic note: a place for DNA-DNA reassociation and 16S rRNA sequence analysis in the present species definition in bacteriology. Int J Syst Bacteriol 44, 846-849.

Stanlake, G. J. \& Finn, R. K. (1982). Isolation and characterization of a pentachlorophenol-degrading bacterium. Appl Environ Microbiol 44, 1421-1427.

Stoltzfus, J. R., So, R., Malarvithi, P. P., Ladha, J. K. \& de Bruijn, F. J. (1997). Isolation of endophytic bacteria from rice and assessment of their potential for supplying rice with biologically fixed nitrogen. Plant Soil 194, 25-36.

Thompson, J. D., Gibson, T. J., Plewniak, F., Jeanmougin, F. \& Higgins, D. G. (1997). The CLUSTAL_X windows interface: flexible strategies for multiple sequence alignment aided by quality analysis tools. Nucleic Acids Res 25, 4876-4882.

Valo, R., Kitunen, V., Salkinoja-Salonen, M. \& Räisänen, S. (1984). Chlorinated phenols as contaminants of soil and water in the vicinity of two Finnish sawmills. Chemosphere 13, 835-844.

Valo, R., Kitunen, V., Salkinoja-Salonen, M. S. \& Räisänen, S. (1985). Chlorinated phenols and their derivatives in soil and ground water around wood-preserving facilities in Finland. Water Sci Technol 17, 1381-1384.

Valverde, A., Velázquez, E., Gutiérrez, C., Cervantes, E., Ventosa, A. \& Igual, J.-M. (2003). Herbaspirillum lusitanum sp. nov., a novel nitrogen-fixing bacterium associated with root nodules of Phaseolus vulgaris. Int J Syst Evol Microbiol 53, 1979-1983.

Wayne, L. G., Brenner, D. J., Colwell, R. R. \& 9 other authors (1987). International Committee on Systematic Bacteriology. Report of the ad hoc committee on reconciliation of approaches to bacterial systematics. Int J Syst Bacteriol 37, 463-464.

Weisburg, W. G., Barns, S. M., Pelletier, D. A. \& Lane, D. J. (1991). 16 S ribosomal DNA amplification for phylogenetic study. J Bacteriol 173, 697-703.

Yong, J. P. W. (1992). Phylogenetic classification of nitrogen-fixing organisms. In Biological Nitrogen Fixation, pp. 43-86. Edited by G. Stacey, R. H. Burris \& H. J. Evans. New York: Chapman \& Hall. 